\title{
Clinical course of extensively drug-resistant tuberculosis with HIV infection and tertiary syphilis: a case report
}

\author{
O. M. Raznatovska*1,A,C-F, A. V. Fedorets ${ }^{2, A, B}$, O. O. Furyk $k^{1, C, E, F}$, H. I. Makurina ${ }^{1, E, F}$, \\ T. O. Hrekova ${ }^{1, D, F}$, V. V. Romashchenko $0^{3, C}$
}

${ }^{1}$ Zaporizhzhia State Medical University, Ukraine, ${ }^{2}$ Municipal Institution “Zaporizhzhia Regional Tuberculosis Clinical Dispensary”, Ukraine, ${ }^{3}$ Municipal Institution "Zaporizhzhia Regional Pathological Anatomy Bureau", Ukraine

A - research concept and design; B - collection and/or assembly of data; C - data analysis and interpretation; D - writing the article; $\mathrm{E}$ - critical revision of the article; $\mathrm{F}$ - final approval of the article

Key words: tuberculosis, HIV, syphilis.

Pathologia 2019; 16 (3), 424-430 DOl:

10.14739/2310-1237 2019.3.189001

*E-mail: raxnatovskaya@ gmail.com
Purpose. To update the literature data with the clinical features of extensively drug-resistant tuberculosis (XDR-TB), HIV and tertiary syphilis co-infection course based on an example from own clinical experience.

Materials and methods. A case report of XDR-TB with HIV and tertiary syphilis co-infection course was described based on our own clinical experience.

Results. The presented clinical case confirms the partial literature data as we did not find such a combined course of XDR-TB with HIV infection and tertiary syphilis in the literature available. So, XDR-TB developed in the patient due to late diagnosed and untreated HIV infection. Neurosyphilis praecox developed secondary to Lues latens ignorata. Early diagnosis of tertiary syphilis was problematic owing to considerable similarity of XDR-TB and HIV infection clinical manifestations. The CD4+ T-lymphocyte count was 16 cells (with a viral load of 3483783 RNA copies $/ \mathrm{ml}$ ) indicating a pronounced immune system inhibition in the patient, causing progressive multiple organ failure, HIV-associated diseases (nephropathy, encephalopathy, cardiomyopathy) and visceral tertiary syphilis (the kidney and brain). Despite multimodality therapy (antimycobacterial, antiretroviral, symptomatic and pathogenetic therapy, treatment of syphilis), the patient died after 4 months of inpatient treatment. The immediate causes of death were wasting syndrome, mycobacteriosis, HIV infection-associated diseases manifested as mycobacterial infection and multiple diseases.

Conclusions. Taking into account the considerable similarity of clinical and histological manifestations of tuberculosis and syphilis, as well as frequent HIV-associated tuberculosis (especially CRTB), it is recommended not to neglect the continuous use of a serological panel in patients with HIV and tuberculosis co-infection with the view to timely syphilis detecting. General practitioners are encouraged to work with patients towards the timely HIV testing. Also, it should be kept in mind that timely diagnosed diseases could be treated early, that will help save lives of our patients.
Киючові слова:

туберкульоз,

ВІ^, сифіліс.

Патологія. - 2019. -

T. 16, № 3(47). -

C. $424-430$

\section{Клінічний випадок поєднаного перебігу туберкульозу з широкою лікарською стійкістю з ВІА-інфекцією та третинним сифікісом}

\section{О. М. Разнатовська, А. В. Федорець, О. О. Фурик, Г. І. Макуріна, Т. А. Грекова, В. В. Ромащенко}

Мета роботи - доповнення відомостей фахової літератури клінічними особливостями поєднаного перебігу туберкульозу з широкою лікарською стійкістю (ШЛС-ТБ) із ВІЛ-інфекцією та третинним сифілісом на прикладі власного спостереження з практики.

Матеріали та методи. Описано клінічний випадок власного спостереження поєднаного перебігу ШЛС-ТБ із ВІЛ-інфекцією та третинним сифрілісом.

Результати. Наведений клінічний випадок підтверджує часткові дані наукової літератури, оскільки протягом дослідження не знайшли такого поєднаного перебігу ШЛС-ТБ із ВІЛ-інфекцією та третинним сифілісом у доступних фрахових джерелах. Так, у пацієнтки на тлі пізно діагностованої та нелікованої ВІЛ-інфекції виник ШЛС-ТБ. Neurosyphilis praecox розвинувся на тлі Lues latens ignoratae. Рання діагностика третинного сифілісу була складною через схожість клінічних проявів ШЛС-ТБ і ВІЛ-інфекції. Кількість CD4-лімфоцитів становила 16 клітин (при вірусному навантаженні 3483783 РНК-копій/мл), що вказувало на виражене пригнічення імунної системи у хворої та, як наслідок, стало основою для прогресування поліорганної недостатності, ВІЛ-асоційованих захворювань (нефропатії, енцефалопатії, кардіоміопатії) та третинного вісцерального сифілісу (нирок і головного мозку). Незважаючи на проведення масивної комплексної терапії (антимікобактеріальна, антиретровірусна, симптоматична та патогенетична терапії, лікування сифілісу), пацієнтка померла через 4 місяці стаціонарного лікування. Безпосередніми причинами смерті стали синдром виснаження, мікобактеріоз, захворювання, зумовлене ВІЛ-інфекцією з проявами мікобактеріальної інфекції та множинних захворювань.

Висновки. Враховуючи суттєву схожість клінічних і гістологічних проявів туберкульозу та сифілісу, а також часте приєднання туберкульозу (особливо хіміорезистентого) до ВІЛ-інфекції, у хворих на ВІЛ-інфекцію та туберкульоз рекомендовано не нехтувати постійним застосуванням комплексу серологічних досліджень для своєчасного виявлення в організмі збудника сифілісу. Рекомендацією для сімейних лікарів є робота з пацієнтами в напрямі своєчасного тестування на ВІЛ-інфекцію. Потрібно пам'ятати: своєчасно діагностовані захворювання будуть своєчасно проліковані, що дає змогу врятувати життя пацієнтів. 


\section{Клинический случай сочетанного течения туберкулеза с широкой мекарственной устойчивостью с ВИЧ-инфекцией и третичным сифилисом}

\section{Е. Н. Разнатовская, А. В. Федорец, Е. А. Фурик, Г. И. Макурина, Т. А. Грекова, В. В. Ромащенко}

Цель работы - дополнение сведений научной литературы клиническими особенностями сочетанного течения туберкулеза с широкой лекарственной устойчивостью (ШЛУ-ТБ) с ВИЧ-инфекцией и третичным сифилисом на примере собственного наблюдения из практики.

Материалы и методы. Описан клинический случай собственного наблюдения сочетанного течения ШЛУ-ТБ с ВИЧ-инфекцией и третичным сифилисом.

Результаты. Представленный клинический случай подтверждает частичные данные научной литературы, поскольку такого сочетанного течения ШЛУ-ТБ с ВИЧ-инфекцией и третичным сифилисом в доступных специализированных источниках не нашли. Так, у пациентки на фоне поздно диагностированной и нелеченной ВИЧ-инфекции развился ШЛУ-ТБ. Neurosyphilis praecoх развился на фоне Lues latens ignoratae. Ранняя диагностика третичного сифилиса была сложной из-за значительного сходства клинических проявлений ШЛУ-ТБ и ВИЧ-инфекции. Количество CD4-лимфоцитов составило 16 клеток (при вирусной нагрузке 3483783 РНК-копий/мл), что указывало на выраженное угнетение иммунной системы у больной и, как следствие, стало основой для прогрессирования полиорганной недостаточности, ВИЧ-ассоциированных заболеваний (нефропатии, энцефалопатии, кардиомиопатии) и третичного висцерального сифилиса (почек и головного мозга). Несмотря на проведение массивной комплексной терапии (антимикобактериальная, антиретровирусная, симптоматическая и патогенетическая терапии, лечение сифилиса), пациентка умерла через 4 месяца стационарного лечения. Непосредственными причинами смерти стали синдром истощения, микобактериоз, заболевание, обусловленное ВИЧ-инфекцией с проявлениями микобактериальной инфекции и множественных заболеваний.

Выводы. Учитывая значительное сходство клинических и гистологических проявлений туберкулеза и сифилиса, а также частое присоединение к ВИЧ-инсекции туберкулеза (особенно химиорезистентного), у больных ВИЧ-инсеекцией и туберкулезом рекомендовано не пренебрегать постоянным применением комплекса серологических исследований для своевременного обнаружения возбудителя сифилиса в организме. Рекомендацией для семейных врачей является работа с пациентами в направлении своевременного тестирования на ВИЧ-инфекцию. Надо помнить: своевременно диагностированные заболевания будут своевременно пролечены, что позволит спасти жизни пациентов.

Today, chemoresistant tuberculosis (CRTB) is a global health concern, since its incidence is detected all over the world, but the effectiveness of treatment remains low [1]. Human immunodeficiency virus (HIV) infection I acquired immunodeficiency syndrome (AIDS) is characterized by the development of opportunistic diseases that complicate both the disease course and its treatment. Tuberculosis is the most common among such diseases. Particularly unfavorable is CRTB and HIVI AIDS co-infection.

Syphilis is a disease which can be asymptomatic and last for many years [2]. According to the literature sources [3,4], syphilis epidemiology, in the current context, is marked by an increase in the incidence of early latent syphilis and its late forms, among which neurosyphilis is prevalent.

Borisenko V. V. et al. [5] found that latent syphilis in untreated or ineffectively treated patients can cause damage to the nervous system, which is not consistent with late neurosyphilis, leapfrogging its active forms. Patients' immune system state may also contribute to syphilis pathogenesis.

All three diseases (CRTB, HIV infection /AIDS and syphilis) are very severe having a mutually reinforcing nature. Awareness of these diseases comorbidity is essential for timely and early diagnosis and thus, for a treatment course determination.

\section{The purpose}

To update the literature data with the clinical features of extensively drug-resistant tuberculosis (XDR-TB), HIV and tertiary syphilis co-infection course based on an example from own clinical experience.

\section{Materials and methods}

A case report of XDR-TB with HIV and tertiary syphilis co-infection course was described based on our own clinical experience. A patient received inpatient treatment in the Department of Pulmonary Tuberculosis No 3 of the Clinical Site of Phthisiology and Pulmonology Department of ZSMU at the Municipal Institution "Zaporizhzhia Regional Tuberculosis Clinical Dispensary" (ZRTBCD).

\section{Clinical case presentation}

A 64-year-old woman K. was in a therapeutic department of a city hospital for 26 days. She was admitted complaining of generalized weakness, severe headache, non-productive cough, loss of appetite, weight loss (10 kg), exertional dyspnea, periodic fever over the past 2 months. She did not seek any medical assistance, only took paracetamol for fever. The patient denied a history of tuberculosis, sexually transmitted diseases, viral hepatitis and diabetes mellitus.

On admission, the patient was diagnosed with a severe general condition, temporal disorientation, but she was alert. Auscultation of the chest revealed bilateral harsh breathing, no rales. Clinical blood analysis (CBA) was as follows: hemoglobin $(\mathrm{Hb})-156 \mathrm{~g} /$; ; erythrocytes $(\mathrm{Er})$ $5,18 \times 10^{12} /$, leukocytes (L) $-17,0 \times 10^{9} /$, erythrocyte sedimentation rate (ESR) $-16 \mathrm{~mm} / \mathrm{h}$, bands (b) $-11 \%$, segmented neutrophils (s) $-78 \%$, eosinophils (e) $-0 \%$,
Киючевые слова: туберкулез, ВИЧ, сифилис.

Патология. - 2019. T. 16, № 3(47). C. $424-430$ 


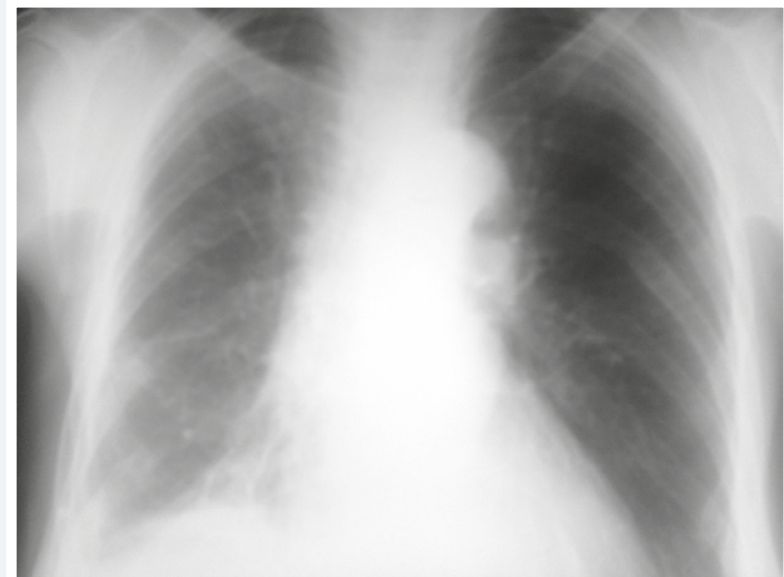

Fig. 1. Chest radiograph on admission showing circumscribed right hydrothorax.

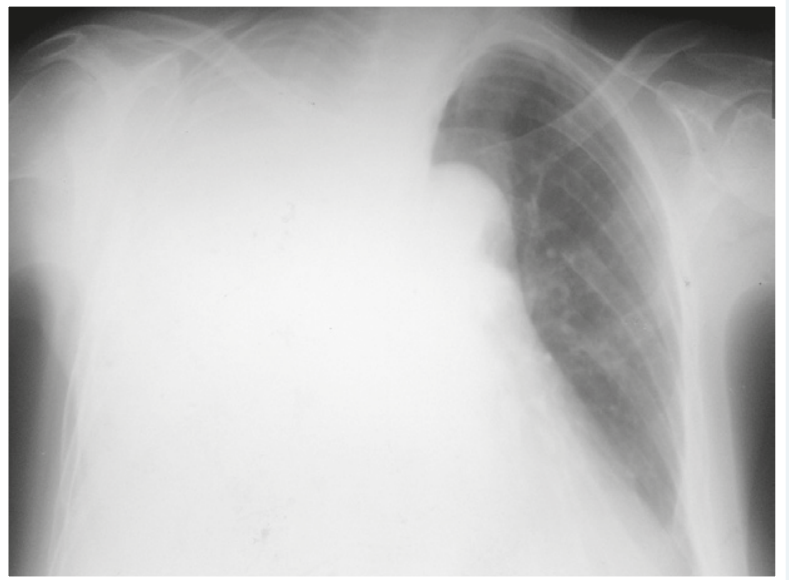

Fig. 2. Chest radiograph in 6 hours after admission showing total right hydrothorax. lymphocytes (I) $-7 \%$, monocytes $(\mathrm{m})-4 \%$. She had negative MTB sputum smear. Chest radiograph showed a circumscribed right hydrothorax (Fig. 1).

However, symptoms of dyspnea seriously worsened in 6 hours and, as a result, a comparison radiograph was taken (Fig. 2). Total right hydrothorax was diagnosed.

A pleural puncture with a pleural effusion analysis showed $1100 \mathrm{ml}$ of turbid yellowish fluid having a specific gravity of 1014, the Rivalta test yielded a positive result, protein level of $16.5 \mathrm{~g} / \mathrm{l}, \mathrm{Er}-2 / 3$ per field of vision (FOV), $\mathrm{L}-20-30$ per FOV, $\mathrm{I}-87 \%$, single mesothelial cells. The pleural fluid samples were negative for Mycobacterium tuberculosis (MBT) and atypical cells (AC). The pleural fluid was taken on a liquid culture medium.

Exudative right-sided pleurisy, exudative phase was diagnosed.

The patient underwent complete examination when staying in the hospital:

- Electrocardiogram (ECG): sinus rhythm, adequate voltage, left electric axis deviation, left ventricular hypertrophy, incomplete left bundle-branch block.

- Gynecological findings: no acute gynecological pathology was detected at the time of examination.

- The patient flatly refused to test blood for HIV antibodies (AB).

- Ultrasound (US) of the urinary system revealed echo signs of the pyelocaliceal system diffuse thickening, right-sided nephroptosis.

- Abdominal US showed echo signs of fatty hepatosis, gallstone disease, chronic calculous cholecystitis and diffuse parenchymal changes of the pancreas.

- Fibrogastroduodenoscopy showed erosive-atrophic gastropathy.

- Ophthalmological findings: early-stage cataract.

On the $24^{\text {th }}$ day of inpatient treatment, the patient underwent further US of the pleural cavity and fibrobronchoscopy (FBS):

- FBS showed diffuse bilateral catarrhal-erosive endobronchitis of 1-2 degrees. Bronchial washings were collected for molecular genetic (MG) testing for MBT detection.
- US of the pleural cavity showed right-sided exudative pleurisy with signs of loculation and pleural adhesions. Pleural puncture and pleural fluid analysis were performed.

The following day, the pleural fluid showed an increased total cell count with the predominance of segmented neutrophils at different stages of destruction and was positive for MBT (1+). Bronchial washings were also positive for MBT resistant to rifampicin (Rif+).

Liver function test were within normal limits during inpatient treatment.

Taking into account the latest data with the diagnosis of rifampicin resistant tuberculosis (RifTB), extrapulmonary tuberculosis (EPTB), right-sided exudative pleurisy, exudative phase, $\mathrm{MBT}(+), \mathrm{M}(-), \mathrm{MG}(+)$, Rif(+), category 4 (newly diagnosed tuberculosis (NDTB)), the patient was transferred to the ZRTBCD.

CBA at discharge from the hospital: $\mathrm{Hb}-130 \mathrm{~g} /$; $\mathrm{Er}-4.49 \times 10^{12} / \mathrm{l}, \mathrm{L}-6.1 \times 10^{\%} / \mathrm{l}, \mathrm{ESR}-14 \mathrm{~mm} / \mathrm{h}, \mathrm{b}-2 \%$, s $-77 \%, e-1 \%, I-13 \%, m-7 \%$.

The patient was admitted to the ZRTBCD in an extremely serious condition. A comparison radiograph was taken showing right-sided hydrothorax up to the level of the $2^{\text {nd }}-3^{\text {rd }}$ rib; diaphragm and sinuses were undifferentiated; low-density patchy infiltrates in the left upper lobe which were not previously detected.

A pleural puncture was performed with removal of $800 \mathrm{ml}$ of pleural fluid and its analysis revealed a specific gravity of 1014 , protein of $33 \mathrm{~g} / \mathrm{l}$, the Rivalta test was positive (exudate), $\mathrm{Er}-2 / 3$ per FOV; $L-1 / 2-1 / 3$ of FOV, I $-97 \%$, AC and MBT were not detected.

ECG findings: sinus tachycardia (heart rate 104 bpm), adequate voltage, left electric axis deviation, left ventricular hypertrophy, incomplete left bundle-branch block, diffuse myocardial changes.

A sputum smear was positive for MTB (1+) and sputum was taken on a liquid culture medium. The patient had sputum smear negative for Pneumocysts on admission and throughout the entire inpatient treatment.

On the $2^{\text {nd }}$ day of inpatient treatment in the ZRTBCD, the results of pleural fluid culture and drug sensitivity test (DST) performed after the first pleural puncture in 
the therapeutic department, were obtained. It was found that the cultured MBT strain demonstrated resistance to all first-line anti-tuberculosis drugs - isoniazid $(\mathrm{H})$, rifampicin $(R)$, streptomycin $(S)$, ethambutol $(E)$, pyrazinamide $(Z)$ and to 2 preparations of second-line anti-tuberculosis drugs - kanamycin ( $\mathrm{Km}$ ) and moxifloxacin (Mfx).

Based on the last chest radiograph and the DST findings, the diagnosis was set: XDR-TB of the upper lobe of the right lung (infiltrative), Destruction (-), MBT(+), M(+), MG(+), Rif(+), K(+), Resistance I (HRSEZ), Resistance II (KmMfx). EPTB, right-sided exudative pleurisy, exudative phase, category 4 (NDTB). Antimycobacterial (AMBT) therapy by category 4 was prescribed, taking into account the DST data according to the Unified Clinical Protocol "Tuberculosis" [6].

In the ZRTBCD, the patient consented to test blood for HIV and the result turned out to be positive. Her CD4+ T lymphocyte count was 16 cells $(1.9 \%)$ and serum viral load was 3483783 HIV RNA copies/ml.

Following consultation of an infectious disease specialist, the diagnosis was made: HIV infection (B 20.0), IV clinical stage, oropharyngeal candidiasis.

Biseptol, fluconazole and azithromycin prophylaxis and treatment of opportunistic infections were initially prescribed to the patient. And after 2 months of the AMBT therapy, an antiretroviral therapy (ART) was prescribed by the infectious disease specialist.

Serological Wassermann reaction performed when the patient was admitted to the ZRTBCD tested positive. For this reason, after consulting a dermatovenerologist, the patient was referred to further panel of serological studies (PSS) in order to determine whether or not syphilis (T. pallidum) was confirmed. All the tests turned out to be positive:

- Rapid plasma regain (RPR) reaction was weak positive.

- Passive hemagglutination reaction (PGRA) - positive.

- Blood test using the enzyme-linked immunosorbent assay (ELISA-TREP test system for antibodies to antigenic components of $T$. pallidum screening in human serum or plasma used primarily to confirm the diagnosis of syphilis) was positive. In this case, immunoglobulin responses to individual T. pallidum polypeptides indicated the following results: TpN15 - positive, TpN17 - positive, TpN41 - negative, TpN47 - negative. These tests were performed for three times (once every three weeks) and the results remained unchanged.

Based on the data obtained, the dermatovenerologist diagnosed Lues latens ignorata. An adequate treatment was prescribed.

Almost after a week of AMBT therapy, US examination of her thorax revealed $180 \mathrm{~cm}^{3}$ of loculated pleural effusion in the right pleural cavity.

The patient was further examined by a therapist, and the diagnosis was made: HIV-associated cardiomyopathy, hypertensive nephropathy. I degree heart failure (HF), functional class (FC) II. II-III degree pulmonary insufficiency (PI). Chronic non-alcoholic steatohepatitis, atrophic gastritis. Gallstone disease, chronic calculous cholecystitis, remission phase.

Based on the therapist's report, an adequate symptomatic treatment was prescribed to the patient.
After a month of AMBT therapy, the result of sputum culture (made upon admission to the hospital) and the DST data were obtained: Resistance I (HRSE), Resistance II (KmMfx). The resistance obtained was almost identical to the DST results of the pleural fluid, except for pyrazinamide.

From the second month of inpatient treatment, the patient demonstrated a continued increase in blood thymol turbidity test up to 16.39 units (un) (upper reference limit: $5 \mathrm{un}$ ), variations in the creatinine level from $142.5 \mu \mathrm{mol} / \mathrm{L}$ to $274.0 \mu \mathrm{mol} / \mathrm{L}$ (upper reference limit: $97 \mu \mathrm{mol} / \mathrm{L}$ ) and the urea level from $10.1 \mathrm{mmol} / \mathrm{L}$ to $13.2 \mathrm{mmol} / \mathrm{L}$ (upper reference limit: $7.2 \mathrm{mmol} / \mathrm{L}$ ) as well as increase in the serum urea nitrogen concentration up to $6.16 \mathrm{mmol} / \mathrm{L}$ (upper reference limit: $4.51 \mathrm{mmol} / \mathrm{l}$ ). At that time, anemia and inflammatory process symptoms worsened which manifested as a decrease in $\mathrm{Hb}$ to $70 \mathrm{~g} / \mathrm{l}$ and $\mathrm{Er}$ to $2.62 \times$ $10^{12} / \mathrm{l}, \mathrm{ESR}$ acceleration to $40 \mathrm{~mm} / \mathrm{h}$.

After 2 months of treatment in the ZRTBCD, the patient presented a severe general condition, temporal disorientation, long history of headache and complained of paresthesia in the limbs and speech impairment. Therefore, she was examined by a neurologist, who bearing in mind that the patient was diagnosed with syphilis, referred her for a spinal puncture and liquor examination.

The liquor result indicated protein of $0.0099 \mathrm{~g} / \mathrm{l}$, Pandy's reaction $(+)$,negative Nonne-Apelt test, white blood cell count of 1 cell (I), glucose level of $2.11 \mathrm{mmol} / \mathrm{l}$, chloride level of $106.8 \mathrm{mmol} / /$; AC, MBT and cryptococci were not detected.

Taking into account the results of liquor examination, the dermatovenerologist made the following diagnosis: Early Neurosyphilis praecox, Lues latens ignorata. An adequate treatment regimen was prescribed to the patient.

After 4 months of treatment, a comparison radiograph showed: increased pulmonary vascularity due to the interstitial component in both lung fields, thickened intercostal pleura on the right side, ill-defined diaphragm contour, buried sinus, commissure occupying oblique fissure. Mediastinal organs were shifted to the right (probably due to pleuropneumocirrhosis development).

Despite the multimodality therapy, the patient's general condition progressively deteriorated with an increase in sings of multiple organ failure, and biological death was pronounced after 4 months of inpatient treatment.

Post-mortem diagnosis: HIV infection, IV clinical stage, multiple organ failure. HIV-related diseases: cardiomyopathy, encephalopathy, nephropathy. XDR-TB of the upper lobe of the right lung (infiltrative), Destruction $(-)$, MBT (+), M (+), MG (+), Rif (+), K (+), Resistance I (HRSEZ), Resistance II (KmMfx). EPTB, right-sided exudative pleurisy, resolution phase. Histology 0 . Category 4 (NDTB). II-III degree PI. I degree HF, FC II. Lues latens ignorata. Early Neurosyphilis praecox. Chronic non-alcoholic steatohepatitis. Atrophic gastritis. Gallstone disease. Chronic calculous cholecystitis, remission phase. Chronic anemia. Cachexia.

Pathological-anatomical diagnosis:

1. The main disease. HIV infection, IV clinical stage (according to clinical data). Mycobacterial infection with the upper lobe of the right lung lesion: focal areas of specific productive inflammation, represented by epithelial 


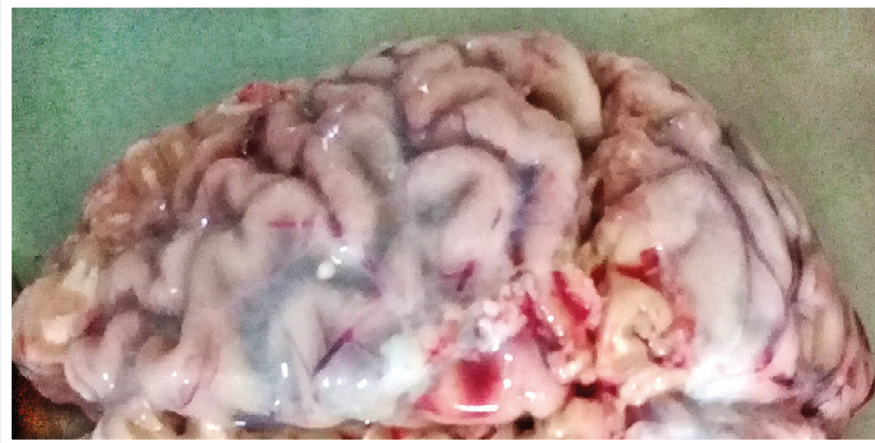

Fig. 3. Tertiary syphilis-induced lesions of the meninges (gross specimen)

cells, macrophages, lymphocytes with the presence of Pirogov-Langhans giant cells and focal zones of caseous necrosis in the centers of individual sites of productive inflammation. HIV-associated multifocal leukoencephalopathy: multiple non-homogeneous foci of honeycomb pattern in the brain white matter, foci of white matter demyelination, perivascular infiltration with lymphocytes, macrophages and siderophages, multiple microglial nodules mainly in the subcortical parts of the brain.

HIV-associated nephropathy: segmental glomerulosclerosis, lymphohistiocytic infiltration of the stroma. Tertiary syphilis (syphilis visceralis) with kidney damage: rounded lesions in the right renal cortex $(1.5 \mathrm{~cm}$ and $1.8 \mathrm{~cm}$ in diameter) demarcated from the rest of the tissue by a capsule consisting of collagen fibers, presenting a central area of colliquative necrosis surrounded by the newly formed granulation tissue infiltrated with lymphocytes, plasma cells, epithelial cells, fibroblasts and occasional Pirogov-Langhans giant cells with the presence of angiomatosis and signs of proliferative vasculitis.

HIV-associated cardiomyopathy. Neurosyphilis: opacification and thickening of pia mater, foci of colliquative necrosis surrounded by chronic inflammatory infiltration containing predominantly lymphocytes, plasma cells and occasional Pirogov-Langhans giant cells with the newly formed granulation tissue. The gross specimens present tertiary syphilis-induced lesions of the cerebellum and the meninges (Fig. 3).

2. Complications. Brain swelling (brain weight of $1350 \mathrm{~g}$ ). Focal selective neuronal necrosis (complete and partial) in the cerebral hemispheric cortex. Endogenous intoxication: focal tubular kidney necrosis, focal centrolobular hepatic necrosis. Right-sided exudative pleurisy (900 ml of exudate in the right pleural cavity). Pulmonary heart disease (right ventricle wall thickness of $0.5 \mathrm{~cm}$ ). Chronic renal failure. Chronic anemia. Venous congestion and parenchymatous degeneration of internal organs.

3. Concomitant diseases. Chronic pancreatitis in remission. Chronic calculous cholecystitis in remission. Chronic superficial erosive gastroduodenitis with I-II degree atrophy, exacerbation phase.

Cause of death:

1. Mode of death: HIV disease resulting in wasting syndrome (B 22.2), HIV disease resulting in mycobacterial infection (B 20.0), HIV disease resulting in multiple diseases (B 22.7).
2. Underlying significant conditions that contributed to death but not related to the disease or its complications which were the direct cause of death: HIV-associated nephropathy and encephalopathy.

Clinical and pathological-anatomical epicrisis:

-When comparing clinical and pathologic-anatomical findings, it was found that HIV-associated mycobacterial infection of the upper lobe of the right lung developed in the patient.

-HIV-associated nephropathy, encephalopathy, cardiomyopathy occurred.

- Tertiary syphilis with the kidney and brain lesions was diagnosed.

-The course of the disease was complicated by the development of right-sided exudative pleurisy of tuberculosis etiology ( $900 \mathrm{ml}$ of exudates in the right pleural cavity), moderate pneumofibrosis with the subsequent development of chronic pulmonary heart disease (right ventricular wall thickness of $0.5 \mathrm{~cm}$ ).

-Syphilitic kidney damage resulted in progressive renal failure. Neurosyphilis caused progressive development of cerebral oedema.

- Progressive multiple organ failure was the direct cause of death in the prevailing conditions with underlying severe endogenous intoxication, cardiorespiratory failure and worsening cerebral oedema.

\section{Discussion}

Rodikov M. V. [7] in his study indicates that late neurosyphilis develops most frequently with underlying latent and late forms of syphilis, the predominant share of which is Lues latens ignorata (58.4\%).

The literature describes a case of neurosyphilis with concomitant cryptococcal and tuberculous meningitis in a patient with AIDS [8]. The authors assert that the immunodeficiency state induced by HIV may facilitate the progression of neurosyphilis which itself can complicate HIV infection at any time after the initial infection. The researchers further indicate that timely diagnosis of meningeal tuberculosis is very challenging in a patient with AIDS as MBT are rarely detected in liquor.

Also, the literature suggests that the risk of developing neurosyphilis in HIV-infected patients increases if the CD4 T-lymphocytes count $<350$ cells $/ \mu$ l [9].

Krasnosel'skikh T. V. and Sokolovskij Ye. V. [10] also report that patients with HIV and syphilis co-infection have a higher risk of developing specific neurological disorders and neurorelapses.

Khammassi N. B. et al. [11] describe the case of secondary syphilis, which was complicated by generalized affection of lymph nodes. Researchers note the difficulties related to differential diagnosis between tuberculosis and syphilis in this case because of considerable similarity of clinical and histological manifestations of these diseases. So, granulomatous inflammation manifesting in granuloma composed of a central zone of caseous necrosis surrounded by Pirogov-Langhans giant cells is characteristic for both diseases. Tuberculosis frequently occurs with the concomitant involvement of intrathoracic as well as peripheral lymph nodes. Therefore, the authors focus on the importance of the disease etiological factors 
(Treponema pallidum and MBT) timely diagnosis using serological tests in the case of syphilis, and MG methods in tuberculosis.

Krasnosel'skikh T. V. et al. [12], describing the case of tertiary syphilis complicated by multiple skin gummas, also emphasize the timeliness of the etiological factor diagnosis. Indeed, the morphological manifestation of gumma in our patient was granuloma with caseous necrosis surrounded by plasma cell infiltrate, which was similar to tuberculosis.

Loseva O. K. et al. [13], studying the case of latent late neurosyphilis in a patient with fibrous-cavernous pulmonary tuberculosis found that the main reason for treatment failure of such patients was the lack of coordination in diagnosis and treatment when doctors of different specialties need to be involved. This factor resulted in both late diagnosis of neurosyphilis and lethal outcome of it in their case.

Mordovskaia L. I. et al. [14] studied tuberculosis and syphilis co-infections in 352 patients. Researchers found that this combined pathology was more common among socially maladjusted male urban population. It was found that this combination was complicated by MBT resistance to antimycobacterial agents in $69.2 \%$ of cases, including $53.4 \%$ of cases diagnosed with multidrug-resistant tuberculosis (MDR-TB) and $12.6 \%$ with XDR-TB.

The presented clinical case confirms the partial literature data as we did not find such a combined course of XDR-TB with HIV infection and tertiary syphilis in the literature available.

So, XDR-TB developed in the patient due to late diagnosed and untreated HIV infection. Neurosyphilis praecox developed secondary to Lues latens ignorata. Early diagnosis of tertiary syphilis was problematic owing to considerable similarity of XDR-TB and HIV infection clinical manifestations. The CD4+ T-lymphocyte count was 16 cells (with a viral load of 3483783 RNA copies/ $\mathrm{ml}$ ) indicating a pronounced immune system inhibition in the patient, causing progressive multiple organ failure, HIV-associated diseases (nephropathy, encephalopathy, cardiomyopathy) and visceral tertiary syphilis (the kidney and brain). Despite multimodality therapy (antimycobacterial, antiretroviral, symptomatic and pathogenetic therapy, treatment of syphilis), the patient died after 4 months of inpatient treatment. The immediate causes of death were wasting syndrome, mycobacteriosis, HIV infection-associated diseases manifested as mycobacterial infection and multiple diseases.

\section{Conclusions}

Taking into account the considerable similarity of clinical and histological manifestations of tuberculosis and syphilis, as well as frequent HIV-associated tuberculosis (especially CRTB), it is recommended not to neglect the continuous use of a serological panel in patients with HIV and tuberculosis co-infection with the view to timely syphilis detecting. General practitioners are encouraged to work with patients towards the timely HIV testing. Also, it should be kept in mind that timely diagnosed diseases could be treated early, that will help save lives of our patients.
Conflicts of interest: authors have no conflict of interest to declare. Конфмікт інтересів: віАсутній.

Надійшла Ао редакції / Received: 15.07.2019

Після Аоопрацювання / Revised: 17.09.2019

Прийнято Ао Аруку / Accepted: 15.10.2019

Information about authors:

Raznatovska O. M., MD, PhD, DSc, Professor, Head of the

Department of Phthisiology and Pulmonology, Zaporizhzhia State

Medical University, Ukraine.

ORCID ID: 0000-0003-2252-9063

Fedorets A. V., Phthisiologist of the Pulmonary Tuberculosis

Department № 3, Municipal Institution "Zaporizhzhia Regional

Tuberculosis Clinical Dispensary", Ukraine.

ORCID ID: 0000-0003-0994-5265

Furyk 0. O., MD, PhD, Associate Professor of the Department of Infectious Diseases, Zaporizhzhia State Medical University,

Ukraine.

ORCID ID: 0000-0002-5196-7698

Makurina H. I., MD, PhD, DSc, Head of the Department of

Dermatovenerology and Cosmetology with the Course of Aesthetic Medicine of FPE, Zaporizhzhia State Medical University, Ukraine. ORCID ID: 0000-0002-3293-2748

Hrekova T. O., MD, PhD, Associate Professor of the Department of Pathological Physiology, Zaporizhzhia State Medical University, Ukraine.

ORCID ID: 0000-0001-9946-3336

Romashchenko V. V., Pathologist, Municipal Institution

"Zaporizhzhia Regional Pathological Anatomy Bureau",

Ukraine.

Відомості про авторів:

Разнатовська 0. М., А-р меА. наук, професор, зав. каф. фтизіатрії і пульмонології, Запорізький Аержавний медичний університет, Україна.

ФеАорець А. В., лікар-фтизіатр віААілення легеневого туберкульозу № 3, КУ “Запорізький обласний протитуберкульозний кмінічний Аиспансер", Україна. Фурик О. О., канА. меА. наук, Аоцент каф. інфекційних хвороб, Запорізький державний медичний університет, Україна.

Макуріна Г. І., А-р меА. наук, зав. каф. Аерматовенерології та косметології з курсом Аерматовенерології і естетичної медицини ФПО, Запорізький Аержавний меАичний університет, Україна.

Грекова Т. А., канА. меА. наук, Аоцент каф. патологічної фізіології, Запорізький державний медичний університет, Україна.

Ромащенко В. В., патологоанатом, КУ «Запорізьке обласне патологоанатомічне бюро", Україна.

\section{Сведения об авторах:}

Разнатовская Е. Н., А-р меА. наук, профессор,

зав. каф. фтизиатрии и пульмонологии, Запорожский государственный медицинский университет, Украина. ФеАорец А. В., врач-фтизиатр отАеления кегочного туберкулеза № 3, КУ «Запорожский областной противотуберкулезный киинический Аиспансер", Украина.

Фурик Е. А., канА. меА. наук, Аоцент каф. инфекционных болезней, Запорожский государственный медицинский университет, Украина.

Макурина Г. И., А-р меА. наук, зав. каф. Аерматовенерологии и косметологии с курсом Аерматовенерологии и эстетической медицины ФПО, Запорожский государственный меАицинский университет, Украина.

Грекова Т. А., канА. меА. наук, Аоцент каф. патологической физиологии, Запорожский государственный меАицинский университет, Украина.

Ромащенко В. В., патологоанатом, КУ «Запорожское областное патологоанатомическое бюро", Украина.

\section{References}

[1] Global tuberculosis report 2019. (2019, November 18). Retrieved from https://www.who.int/tb/publications/global__eport/en/. 
[2] Genovese, G., Nazzaro, G., Coggi, A., Gianotti, R., Ramoni, S., \& Cusini, M. (2018). Secondary syphilis masquerading as lupus vulgaris in an HIV-infected patient: A diagnosis suggested by histology. International Journal of STD and AIDS, 29(14), 1454-1456. https://doi. org/10.1177/0956462418795590

[3] Potekaev, N. N., Frigo, N. V., Almazova, A. A., \& Lebedeva, G. A (2015). Ehpidemiologiya sifilisa v sovremennykh usloviyakh [Syphilis epidemiology under modern conditions]. Klinicheskaya dermatologiya i venerologiya, 1, 22-34. [in Russian]. https://doi.org/10.17116/klinderma2015122-34

[4] Shubina, A. S. (2016). Ehpidemiologicheskie aspekty zabolevaemosti neirosifilisom [Epidemiological aspects of disease neurosyphilis]. Mezhdunarodnyi zhurnal ehksperimental'nogo obrazovaniya, 4-3, 427-429. [in Russian]. Retrieved from http://www.expeducation.ru/ru/ article/view?id=9816

[5] Borisenko, V. V., Noskova, A. V., \& Grin' I. A. (2011). Klinicheskii sluchai manifestatsii neirosifilisa na fone toksicheskogo gepatita, vyzvannogo otravleniem dikorastushchimi yadovitymi gribami [Clinical case of manifestation of neurosyphilis| on a background toxic hepatitis, caused poisoning growings wild poisonous mushrooms]. Ukrainskyi zhurnal ekstremalnoi medytsyny imeni H.O. Mozhaieva, 12 (3), 141-144. [in Russian].

[6] Ukraina MOZ. (2014). Unifikovanyi klinichnyi protokol pervynnoi, vtorynnoi (spetsializovanoi) ta tretynnoi (vysokospetsializovanoi) medychno dopomohy doroslym. Tuberkulioz: nakaz MOZ Ukrainy № 620 vid 31.12.2014 r. [Unified clinical protocols of primary, secondary (specialized) and tertiary (highly specialized) medical care for adults "Tuberculosis"from December 31, 2014 no 620]. [in Ukrainian]. Retrieved from https://zakon.rada.gov.ua/rada/show/v0620282-14?lang=uk

[7] Rodikov M. V. (2009). Pozdnii neirosifilis (kliniko-epidemiologicheskaya kharakteristika, mekhanizmy razvitiya, optimizatsiya terapii) [Late neurosyphilis (clinical and epidemiological characteristics, developmental mechanisms, optimization of therapy) (Doctoral dissertation). Irkutsk State Institute for Advanced Medical Studies, Irkutsk. [in Russian].

[8] Zamora, J. A. G., Espinoza, L. A., \& Nwanyanwu, R. N. (2017). Neurosyphilis with Concomitant Cryptococcal and Tuberculous Meningitis in a Patient with AIDS: Report of a Unique Case. Case Reports in Infectious Diseases. https://doi.org/10.1155/2017/4103858

[9] Ho, E. L., \& Spudich, S. S. (2015). Neurosyphilis and the impact of HIV infection. Sexual Health, 12(2), 148-154. https://doi.org/10.1071/ sh14195

[10] Krasnoselskikh, T. V., \& Sokolovskiy, E. V. (2015). Neirosifilis na fone VICh-infektsii [Neurosyphilis in HIV-infected patients]. Vestnik dermatologii $i$ venerologii, 2, 49-57. [in Russian]. https://doi. org/10.25208/0042-4609-2015-0-2-49-57

[11] Khammassi, N., Gargoura, A., Abdelhedi, H., Kort, Y., Mabrouk, M., \& Cherif, O. (2015). Generalized lymphadenopathy: An unusual presentation of syphilis. British Journal of Medical Practitioners, 8(3), a827.

[12] Krasnoselskikh, T. V., Mikheev, G. N., Grigorian, A. E., Yastrebov V. V., \& Sokolovskiy, E. V. (2015). Sluchai tretichnogo sifilisa, proyavivshegosya mnozhestvennymi gummami kozhi [A case of tertiary syphilis manifested with multiple skin gummas]. Vestnik dermatologi $i$ venerologii, 2, 84-93. [in Russian]. https://doi.org/10.25208/0042 4609-2015-0-2-84-93

[13] Loseva, O. K., Zalevskaya, O. V., Zyuzya, Y. U. R. \& Stribuk, P. V. (2018). Late neurosyphilis in a patient with pulmonary tuberculosis. The russian journal of clinical dermatology and venereology, 4, 35-44. [in Russian]. https://doi.org/10.17116/klinderma20181704135.

[14] Mordovskaya, L. I., Pavlov, N. G., Alekseeva, S. D., Alekseeva, E. A., \& Dzhemakulova, N. M. (2016). Lekarstvennaya ustoichivost' mikobakterii tuberkuleza u bol'nykh s sochetannoi infektsiei: tuberkulez i sifilis [Drug resistance of tuberculosis microbacteria among patients with combination of tuberculosis and syphilis]. Vestnik severo-vostochnogo federal'nogo universiteta imeni M. K. Ammosova, 3 (04), 49-51. [in Russian]. 